[Phenomenology in Drohobych: «Awakening Visions» by Bruno Schulz]. Filosofs'ka dumka. No. 2. Pp. 90-98. (in Ukrainian).

31. Terner V. U. (1983). Simvol i ritual [Symbol and ritual]. Moscow: Nauka. 480 p. (in Russian).

32. Cheromushnikova I. I. (2010). Vozmozhnosti testa Lyushera (8-tsvetovoy variant) $v$ diagnostike kharakterologicheskikh i povedencheskikh osobennostey studentov s razlichnym urovnem fizicheskoy podgotovki [Possibilities of the Luscher test (8-color version) in the diagnosis of characterological and behavioral characteristics of students with different levels of physical fitness]: author. dis. ... Cand. psychol. sciences. Orenburg. 25 p. (in Russian).

33. Shou YA. (2006). Drevniy Yegipet [Ancient Egypt ]. Moscow: Nauka. 206 p. (in Russian).
34. El'kin V. M. (2005). Teatr tsveta i melodii Vashikh strastey. Tsvetovaya psikhologiya i psikhoterapiya shedevrami iskusstva [Theater of color and melody of your passions. Color psychology and psychotherapy with masterpieces of art]. St. Petersburg: Petropolis. 292 p. (in Russian).

35. Estetika: Slovar' [Aesthetics: Dictionary]. (1989). Moscow: Politizdat. 447 p. (in Russian).

36. Yan'shin P. V. (1996). Emotsional'nyy tsvet [Emotional color]. Samara: SamGPU. 218 p. (in Russian).

37. Moscovici S. (1984). The phenomenon of social representations. Social representations / Eds. M. Fair \& S. Moscovici. Cambridge-Paris. Pp. 3-69. (in English).

DOI: https://doi.org/10.17721/2520-2626/2020.27.17

УДК 001.891.3:130.1

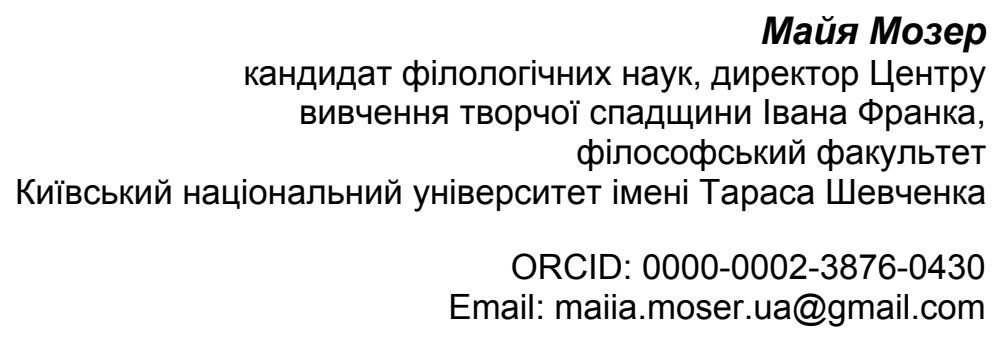

НАЦІОНАЛЬНА ІДЕЯ: АСПЕКТИ КОНФЛІКТИЗАЦІЇ В ЧАСИ МОДЕРНУ

Анотація. Українське суспільство, перебуваючи в стані численних проблемних ситуацій, потребує перегляду стратеаії державобудування. Держава з неконсолідованим суспільством і без чіткої національної ідеї не має майбутнього. Українське суспільствознавство та вітчизняний політикум перебувають в умовах конфрліктизації. Щоб класифрікувати соціальні конфолікти застосовують інтегративний підхід, який $\epsilon$ методологічною основою дослідження щодо аналізу конфрліктів. За інтегративного підходу конфрлікт прийнято розәлядати не лише як руйнівний наратив, джерело смерті, але й як певну зміну, що є зародком нового суспільства, певним поступом. Ми досліджували аспекти конфрліктизації національної ідеї часу модерну на політичних працях Івана Франка.

Народові необхідно сформулювати актуальний зміст такої важливої категорії, як національна ідея. Щоб зберегти територіальну цілісність своєї держави, українство повинно усвідомити природу конфрліктизації, яка, крім розбрату, несе ще й поступ. Для суспільної згуртованості необхідно зорієнтувати народ у кінцевій меті. Щоб сфрормулювати кінцеву мету, слід усвідомити, що значущість досвіду творення національної ідеї та українського національно-державного самовизначення зумовлена чинниками з'ясування сприятливих умов і проблемними історичними аспектами політично-правових й інших суспільних практик.

Ми побачили, що конфрліктизація підвищує рівень конфліктності українського суспільства. Це підсилює його рух, поступ, оскільки в першу чергу конфрліктизація зумовлена біполярністю напрямів, несуголосністю задумів. Тому дуже важливо дотримуватися твердих ідей рішучих людей і пропагувати імплантацію в суспільну свідомість українців національної ідеї.

Ключові слова: національна ідея, часи модерну, класифрікація соціальних конфрліктів, аспекти конфрліктизації.

Maiia Moser

$\mathrm{PhD}$ in Philology, Director of the Center for the Study of Ivan Franko's Creative Heritage, Faculty of Philosophy, Taras Shevchenko National University of Kyiv

\title{
THE NATIONAL IDEA: ASPECTS OF CONFLICTIZATION IN MODERNITY
}

Abstract. Ukraine, which is currently facing of a cluster of various serious problems, has to revise its strategies of state building. A state without a consolidated society and a clear national idea has no future. Ukrainian sociology 
and the political forces are in a situation of ongoing conflictization. It is necessary to formulate and explain the genuine content of the category "national idea", which is crucial for Ukrainian society. To classify social conflicts it is necessary to apply an integrative approach, as the methodological foundation for any analytical study of conflicts. In the framework of an integrative approach conflicts are usually regarded not only as a narrative of ruin, a source of death, but also as a certain change that gives the chance to create a new society, as a source of progress. This study analyzes aspects of the conflictization of the national idea in modernity as exemplified by the political studies of the Ukrainian intellectual Ivan Franko.

To formulate the ultimate goal it is important to note that the importance of the creation of the national idea and Ukrainian national self-determination depends on the clarification of favorable conditions and problematic historical aspects of political, juridical, and other societal practices. In order to preserve their territorial integrity Ukrainians should understand the nature of conflictization, which entails not only a divide, but at the same time progress. To unite society it is necessary to orient the people toward some clearly formulated common goal.

It turns out that conflictization corroborates the level of conflicts of Ukrainian society. This enforces its movement and progress, because conflictization is in the first place determined by a strong bipolarity of trends and disharmony of thoughts. Therefore, it is important to take into account clearly formulated ideas put forward by various opinion leaders and to disseminate them among the population.

Keywords: national idea, from modernity to postmodernity, ckassification of social conflicts, aspects of conflictization.

Постановка проблеми. Збалансований стан і розвиток суспільства значною мірою базується на згуртованості та солідарності нації. Націю фрормує держава. В Україні ж державна стратегія націєбудівництва декларується конструктивістською риторикою, зумовленою історичними аспектами. Народ України вже давно об'єднаний, але завше знаходяться зацікавлені сили, які спекулюють на роз'єднанні. Українське суспільствознавство та вітчизняний політикум в умовах конфліктизації ще й досі не сформулювали актуального змісту такої важливої категорії, як національна ідея.

У нашому дослідженні науковий пошук здійснено із залученням методів структурно-функціонального підходу. Структурно-функціо-нальний підхід спрямовує нас насамперед на аналіз функціонування суспільних явищ та усвідомлення механізмів (суспільних комунікацій), їх відтворення і повторюваності. За Р. Мертоном [7] суспільні комунікації розглядають як певну цілісну систему зі складною структурою створеною елементами та зв'язки між ними. Таку структуру слід проаналізувати, описавши іï суттєві складові елементи, підсистеми, компоненти, зв'язки, властивості, функції та ін. В якості системи можна розглядати будьякий соціальний інститут або організацію.

Ми розглядатимемо суспільні явища в Україні за часів модерну. Часи модерну, як історичний період, це епоха модерну, ансамбль соціокультурних норм якої мав погляди та практики, що виникли внаслідок епох Відродження, Просвітництва XVII та XVIII століть. За Маршаллом Берманом, модерн класифікзують за трьома загальноприйнятими фазами: Ранній модерн - 1500-1789 рр.; Класичний модерн 1789-1900 рр. (у схемі Гобсбаума відповідає довгому XIX ст.) та Пізній модерн - 1900-1989 рр.

Деякі коментатори вважають, що епоха модерну закінчилася 1930 р., Другою світовою війною в 1945 р., а вже у 1980-х або 1990-х роках розпочалася наступна епоха постмодернізму. Ми ж розглядатимемо в нашому дослідженні Пізній модерн, який за Гобсбаумом відповідає довгому XIX ст., оскільки він привів нас до сьогодення. Аналітична концепція та нормативний ідеал цього модерну тісно пов'язані з етосом філософського та естетичного модернізму. Політичні та інтелектуальні течії його перетнулися з Просвітництвом та породили такі події, як фрормальне становлення суспільної науки, сучасні антитетичні розробки, марксизм.

Аналіз наукових публікацій. Щодо дослідже-ння конфліктів варто зазначити, що перші протоконфліктологічні концепції розробляли Т. Гоббс, Ж.Ж. Руссо, А. Сміт, К. Клаузевіц, Ч. Дарвін та ін. Такі їх послідовники, як: М. Дойч, К. Левін, Д. Мід, К. Роджерс, К. Хорні, У.Юрі, уже досліджували соціологічні та психологічні аспекти конфрліктів. В часи модерну вивчення конфрліктизації набирає обертів і її дослідження вже розділяють між соціал-дарвінізмом (Т. Гоббс, Л. Гумплович, Т. Мальтус, У. Самнер, Г. Спенсер), конфліктологічною концепцією за К. Марксом та теорією соціології конфрлікту Г. Зіммеля; концепцію конфрлікту також вивчав К. Боулінг.

Для класифрікації соціальних конфліктів застосовують інтегративний підхід, який є методологічною основою дослідження аналізу конфліктів. За такого підходу конфлікт прийнято розглядати не лише як руйнівний наратив, джерело смерті, але й як певну зміну, що $€$ зародком нового суспільства, певним поступом.

Мета статті - дослідити аспекти конфліктизації національної ідеї часів модерну на політичних працях Івана Франка.

Виклад основного матеріалу. Аспекти конфрліктизації в часи модерну структурують таким чином:

1) Конфлікт уже розглядають як невід'ємний атрибут людського існування, зумовлений суперечливим поєднанням єдності природи і соціуму, природи і культури, культури і соціуму, соціуму і людини, а далі вже людини і людини.

2) У будь-якому суспільстві конфлікт виступає формою життєдіяльності. В часи модерну технічний 
розвиток призводить до конфрлікту як необхідності їх причини соціальної взаємодії як індивідів, так i людських угруповань, суспільних об'єднань, громад.

3) В історії людської цивілізації конфлікт набував значення спрямованих потреб, інтересів, переконань, думок, соціальних установок, цінностей, намірів, позицій суб'єктів взаємодії (які могли бути опонентами, ворогами тощо). Суб'єкти взаємодії стають опонентами тоді, коли один із них зчиняє конфліктну взаємодію, зумовлену просуванням власних інтересів, які не відповідають інтересам іншого суб'єкта.

4) Конфрліктизація, будучи процесом підвищення рівня конфліктності спільноти, набуває значення руху, поступу, оскільки в першу чергу вона зумовлена біполярністю напрямів, несуголосністю задумів.

Аспекти конфліктизації ми розглянемо на прикладі національної ідеї. Саме поняття «національна ідея» започатковане як форма геґелівського абсолютизму у XVIII-XIX ст. для кожного народу. Національні традиції, психологія, спосіб життя породили такі загальні гасла, як: «Православ'я, самодержавство, народність»; «Прав, Британіє, морями»; «Deutschland über alles!» та ін.

Основи для ідейного формування української нації заклав у XIX ст. Тарас Шевченко, якого вважають «батьком» національного відродження. Хоча він і не створив жодного статуту чи то програмової статті, але його твір «I мертвим, і живим, і ненарожденним» [15], як нарис національної ідеї, заклав базис політичної ідеології народу. Його наступниками були творці першої української таємної політичної організаціїКирило-Мефодіївського братства (товариства), членами якого були вихованці й викладачі Київського та Харківського університетів. Провідну роль серед них відігравали М. Костомаров, Т. Шевченко, Г. Андрузький, В. Білозерський, М. Гулак, П. Куліш. Одного із них - М. Костомарова - вважають гіпотетичним автором праці, створеної у форматі біблійного оповідання - «Книга буття українського народу» («Закон Божий») [5]. У ній було закладено низку прогресивних положень, зокрема про необхідність ліквідації кріпосного права та національної нерівності, знищення дворянських привілеїв і станів, а також об'єднання слов'янських народів у фредеративну республіку з парламентським ладом, із наданням кожному народові автономії та рівних прав. Наступним провідником творення національної ідеї вважають брата письменниці та громадської діячки Олени Пчілки, дядька Лесі Українки - українського публіциста, історика, філософра, економіста, літературознавця, фольклориста, громадського діяча, засновника українського соціалізму Михайла Драгоманова. Науковий орган Історичної секції Академії наук України у 1926 р. характеризував його таким, хто став «для одних взірцем всякої досконалости, а для других символом повної духової руїни. Одні називають його "ідеольоґом Вільної України", “апостолом правди й науки”, і пишаються тим, що в 1917 році "великий дух Драгоманова тріюмфував" та що "держава Української Центральної Ради - це овоч засіяних Драгомановим ідей українського соціялізму"; а другі вже і в часах Драгоманова і сьогодні оцінюють його думки як небезпечну отруту, що заподіяла вже багато шкоди нашому національному орґанізмові, а на будуче загрожує нам катастрофральними наслідками» [9].

Найвизначнішим учнем Михайла Драгоманова став Іван Франко. Його на той час займала фундаментальна ідея єдності українського народу. Актуалізації такої ідеї соборності та ідеї відновлення української державності посередньо сприяли праці М. Драгоманова. У статті «Суспільно-політичні погляди М. Драгоманова» І. Франко вказував на те, що «треба мати на увазі той оригінальний і зовсім не науковий демократизм Драгоманова, по якому український "народ" - се лише мужики та робітники, plebs, що говорять українською мовою. Коли б було можливе, що вся суспільність, уся інтелігенція перейнялась би таким “демократизмом”, то над нами як над нацією була б висипана могила» [10, с. 437]. Проте не один І. Франко звинувачував Драгоманова у русофільстві та соціалістичному анархізмі. Навіть голова УНР Михайло Грушевський вважав, що така ідеологія могла б занапастити українство.

Наприкінці XIX - на початку XX століття українська нація перебувала у складному процесі свого фрормування. Національно-визвольна боротьба за незалежність українського народу 1917-1921рр., яка супроводжувалася протистоянням різних політичних сил, стала міцним підґрунтям для формування національної української ідеї. Так постали на практичнонаукових і теоретичних засадах праці Михайла Грушевського, Дмитра Донцова, В'ячеслава Липинського, Миколи Сціборського, Івана та Юрія Липи, Володимира Винниченка, Миколи Міхновського й інших.

Значущість досвіду творення національної ідеї, яка пройшла складний і тривалий шлях розвитку, та українського національно-державного самовизначення зумовлена проблемними історичними аспектами політично-правових й інших суспільних практик.

Постає питання: що бачать фахівці в понятті національної ідеї для сучасної України на етапі сьогодення? Ніяких перспектив! Суспільство в розпачі від усвідомлення сучасного стану, так би мовити, «модерної України». У проблемі «національна ідея модерної України» вбачаються два різних наративи: наратив «національної ідеї» та наратив «модерної країни», проте вони радикально безперспективні. За словами Оксани Забужко: «Українське суспільство сьогодні позбавлене орієнтирів» [4].

А що ж бачили громадські діячі в часи модерну? Для І. Франка важливим елементом національної ідеї було усвідомлення певного національного ідеалу та намагання працювати над його практичною реалізацією [12]. Утворення української національної держави відбулося завдяки діяльності національної 
еліти як окремого суспільного прошарку. Проте національна ідея при цьому не була повною мірою адаптована широкими соціальними верствами. Участь широких мас у демократичному процесі $\epsilon$ фрактором ризику, що ускладнює загальний розвиток нації. Функціонування національної держави як політичного інституту забезпечує якісний стан суспільства, що спроможне відобразити демократичне волевиявлення і забезпечити реалізацію подальшого самовизначення нації. Для Франка національний ідеал - це духовна основа державної самостійності та національної незалежності українського народу. Він, як ніхто, усвідомлював, що необхідно підняти дух народу, тобто, спрямувати суспільство, незгуртоване, «замучене», «розбите». Бо цей народ, за словами з поеми «Мойсей», «мов паралітик на роздоріжжу», який «людським презирством ніби струпом вкритий» [12].

Тепер варто зосередити увагу на тому, як Іван Франко працював із громадою. Підняти дух суспільства для Івана Яковича - це сила просвіти малограмотного, малоосвіченого народу. Він прагнув дати можливість сотням тисяч неосвічених пізнати свої права та дати віру в силу громад, тобто поєднати цілі та інтереси. У його політичній статті «Поза межами можливого» ми зустрічаємо наступне: «Не маючи в душі свого національного ідеалу, найкращі українські сили тонули в общеросійськім морі, а ті, що лишилися, на своєму ґрунті попадали в зневіру і апатію» [13].

Іван Франко заповзято поширював просвіт-ницьку інформацію щодо соціальних запитів народу. У політичній статті «Програма галицьких соціалістів» він писав: «Маючи на увазі передусім здобуття політичної влади для народу, рухаймося з урядом, під яким тепер перебуваємо, тому що від нього можемо одержати владу. Бо першим кроком до здобуття політичної влади $€$, як відомо, участь у законодавчій діяльності, бо на перший план ставимо повсюдне право вибору i виборності до парламентських органів, як центральних, так і провінційних, і общинних, 3 якнайповнішим дотриманням виборчої свободи, насамперед прямих виборів і таємного голосування» [14, с. 462.]. Франко підкреслював дотримання громадянами законослухняності, оскільки це даватиме їм змогу «домагатися свободи спілкування і зборів, свободи мови і друку».

У своїй праці «Критичні письма о галицькій інтелігенції» І. Франко окреслює конфлліктність у поступі суспільства[11]. На підставі реальних фрактів він описує світоглядні основи й напрями діяльності двох типів інтеліґенції, сформованих у Галичині. Оскільки мислитель завжди вважав інтеліґенцію рушійною силою національного поступу і розвою, то він із болем відмічає, що сприятливий для українців період «весни народів» не став кроком до усвідомлення себе як нації. Причину Іван Франко вбачає в неспроможності згуртуватись: «Від 1848 р. $є$ В нас різні «народні» і ненародні товариства та общества, а, не говорячи вже о користі 3 них для народу, навіть між інтелігенцією самою не здужали вони виробити товариського духу, не здужали збудити почуття солідарності, не здужали виробити поняття спільної праці. Чому? Бо такої спільної праці у них зовсім нема» [11, с. 76].

Аналіз праць І. Франка дає змогу характеризувати конфліктизацію українського етнокультурного простору в наш час. Велика кількість українців за рахунок довготривалого радянського зросійщення втратила свою національну ідентичність. Такі деструктивні антиукраїнські процеси призводять до посилення конфліктів. Щоб українці вистояли як нація, їм слід стверджувати власну культуру, мову, традиції та звичаї. Причинами, які посилюють конфліктизацію українського соціокультурного простору, $€$ відсутність провідної національної ідеї, тобто, теоретичного концепту, програми 3 потужною організацією, а також об'єднаної еліти, яка би закликала та мотивувала суспільство до солідарності та єдності.

У рамках передвиборної кампанії Місцевих виборів 2020 р. ми проводили дискурс-аналіз та контент-дослідження п'яти пріоритетних партій. У поширюваних ними текстах розташовані послідовно за спадом такі лексеми, як: «розвиток» (0,4\%), «фінансування» $(0,3 \%)$, «підтримка» $(0,2 \%)$; оскільки $€$ найвагомішими чинниками життєвих потреб соціуму. Але лексеми найвизначнішого концепту «ПАТРІОТИЗМ», що відтворювані лексемами «національне» $(0,2 \%)$, «українці» $(0,1 \%)$, мають найнижчий рівень частоти вживаності. Але в усіх політичних текстах усіх кандидатів передвиборної кампанії їхній відсотковий показник покриття частотною лексемою занадто низький для формування національної свідомості українського суспільства.

В рамках круглого столу «Пошук нової української національної ідеї», що проводився під головуванням народного депутата від партії «Опозиційна платформа - За життя» Рената Кузьміна 03 серпня 2020 р., прибічники проросійських інтересів поширювали ідею, пропаговану Володимиром Путіним: «У нас національної ідеї нема». Сам політик Ренат Кузьмін заявив: «у мас, у суспільства, національної ідеї немає. Народу головне бути ситим» [6].

У програмі «Hard з Влащенко» на каналі Zik народний депутат України, позафракційний член групи ВО «Свобода» Андрій Іллєнко пропагує національну ідею так: «Суспільство прагне повновладдя української нації на своїй соборній і самостійній державі. Українці завжди прагнули соборності й об'єднаності. Україна єдина» [1].

Голова Українського інституту національної пам'яті Антон Дробович наполягає на створенні таких «інформаційних острівців», які будуть постійно доносити до громади й закарбовувати в їхній свідомості важливі речі: «Кожна спроба незалежності - це велика перемога. Наша державність - це не 3, 5, 10 чи 30 років, 
а мова йде про сотню років. < .. > Я дуже вірю в людину і в людяність» [3].

Отже, конфрліктизація, означаючи рівень конфліктності українського суспільства, в першу чергу зумовлена полярністю напрямів, несуголосністю задумів його представників. Один із шляхів ії подолання - необхідність імплантації в суспільну свідомість українців національної ідеї. Адже, за словами В'ячеслава Чорновола, «національна ідея означає будувати державу на базі корінної нації. Корінна нація України - українці!» [2].

1. Андрій Іллєнко на каналі Zik у студії «Hard 3 Влащенко» (3 грудня 2019 р.). Інформаційне агентство ZIK. URL: https://zik.ua/tv/videos

2. В'яеслав Чорновіл. Radio Holos fm. (21 березня $2020 \quad$ p.). URL: https://www.youtube.com/watch?v=8BFXaSpIVB4

3. Дробович А. Соборність : як зшити Україну. Історична правда (19 січня 2020 р.) URL: https://www. youtube.com/watch?v=mYPWfQltRPA

4. Забужко О. «Українське суспільство сьогодні позбавлене орієнтирів». Український тиждень. URL: https://tyzhden.ua/Culture/197877

5. Костомарів М. Книги битія Українського Народу / Із передмовою Михайла Возняка. Новітня Бібліотека. Ч. 36. Львів-Київ, 1921. URL: https://archive.org/details/knyhybytiiaukra00kostuoft/pag e/n3/mode/2up

6. Круглий стіл «Пошук нової української національної ідеї» (3 серпня 2020 р.). Інформаційне агентство ZIK. URL: https://zik.ua/tv/video/240833

7. Мертон Р. Социальная теория и социальная структура. Москва : АСТ, Хранитель, 2006. 873 с.

8. Степико М. Українська ідентичність : феномен і засади формування. Київ : Видавництво Національного інституту стратегічних досліджень, 2011. 334 c.

9. Україна : Науковий двомісячник українознавства : орган Історичної секції Академії (б. Українського Наукового Товариства в Київі). Кн. 2-3 (17) / Під заг. редакцією гол. секції акад. М. Грушевського. Київ: Державне видавництво України, 1926. 240 c.

10. Франко І. Філософські праці. Зібрання творів у 50 томах. Т. 45. Київ : Наукова думка, 1986. 578 с.

11.Франко І. Критичні письма о галицькій інтелігенції. Зібрання творів у 50 томах. Київ : Наукова думка, 1986. Т. 26. С. 74-94.

12. Франко І. Мойсей. Вибрані твори у трьох томах. Т. 1. Київ : Дніпро, 1973. 759 с., С. 664-714.

13. Франко І. Поза межами можливого. Будівничий української державності: Хрестоматія політологічних статей Івана Франка / Упоряд. Д. Павличко. Київ : Вид. дім «Києво-Могилянська академія», 2006. С. 301-312.

14. Франко І. Програма галицьких соціалістів. Будівничий української державності: Хрестоматія політологічних статей Івана Франка / Упоряд. Д. Павличко. Київ : Вид. дім «Києво-Могилянська академія», 2006. С. 448-467.

15. Шевченко Т.Г. Кобзар / Упоряд., вступна стаття Р. Лубківського. Львів : Світ, 2013. 408 с.

\section{References}

1. Illienko A. (2020). Na kanali Zik u studii «Hard z Vlashchenko» [on the Zik channel in the studio "Hard with Vlashchenko"]. Informatsiine ahentstvo ZIK. URL: https://zik.ua/tv/videos (in Ukrainian).

2. Chornovil V. (2020). Radio Holos fm. [Radio Holos fm.]. URL: https://www.youtube.com/watch?v=8BFXaSpIVB4 (in Ukrainian).

3. Drobovych A. (2020). Sobornist : yak zshyty Ukrainu. Istorychna Pravda [Unity: how to sew Ukraine. Historical truth]. URL: https://www.youtube.com/watch?v=mYPWfQItRPA (in Ukrainian).

4. Zabuzhko O. (2020). «Ukrainske suspilstvo sohodni pozbavlene oriientyriv» ["Ukrainian society today is deprived of landmarks"]. Ukrainskyi tyzhden. URL: https://tyzhden.ua/Culture/197877 (in Ukrainian).

5. Kostomariv M. (1921). Knyhy bytiia Ukrainskoho Narodu / Iz peredmovoiu Mykhaila Vozniaka [Books of the Genesis of the Ukrainian People / With a foreword by Mykhailo Vozniak.]Novitnia Biblioteka. Ch. 36. Lviv-Kyiv. URL: https://archive.org/details/knyhybytiiaukra00kostuoft/pag e/n3/mode/2up (in Ukrainian).

6. Kruhlyi stil «Poshuk novoi ukrainskoi natsionalnoi idei»[ 6. Round table "Search for a new Ukrainian national idea"] (2020) Informatsiine ahentstvo ZIK. URL: https://zik.ua/tv/video/240833 (in Ukrainian).

7. Merton R. (2006). Sotsyalnaia teoryia i sotsyalnaia struktura [Social theory and social structure]. Moskva : ACT, Khranytel. 873 p. (in Russian).

8. Stepyko M. (2011). Ukrainska identychnist : fenomen i zasady formuvannia [Ukrainian identity: phenomenon and principles of formation.]. Kyiv : Vydavnytstvo Natsionalnoho instytutu stratehichnykh doslidzhen. 334 p. (in Ukrainian).

9. Hrushevskyi M. (ed.). (1926). Ukraina. Naukovyi dvomisiachnyk ukrainoznavstva [Ukraine. Naukovyi dvomisiachnyk ukrainoznavstva]. Kn. 2-3 (17). Kyiv: Derzhavne vydavnytstvo Ukrainy. 240 p. (in Ukrainian).

10. Franko I. (1986). Filosofski pratsi [Philosophical works]. Zibrannia tvoriv u 50 tomakh. Vol. 45. Kyiv : Naukova dumka. 578 p. (in Ukrainian).

11. Franko I. (1986). Krytychni pysma o halytskii intelihentsii [Critical letters about the Galician intelligentsia]. Zibrannia tvoriv u 50 tomakh. Kyiv : Naukova dumka. Vol. 26. Pp. 74-94. (in Ukrainian).

12. Franko I. (1973). Moisei [Moses]. Vybrani tvory u trokh tomakh. T. 1. Kyiv : Dnipro. 759 p. (in Ukrainian). 
13. Franko I. (2006). Poza mezhamy mozhlyvoho [Beyond the possible]. Budivnychyi ukrainskoi derzhavnosti: Khrestomatiia politolohichnykh statei Ivana Franka / Uporiad. D. Pavlychko. Kyiv : Vyd. dim «KyievoMohylianska akademiia». Pp. 301-312. (in Ukrainian).

14. Franko I. (2006). Prohrama halytskykh sotsialistiv [The program of the Galician socialists]. Budivnychyi ukrainskoi derzhavnosti: Khrestomatiia politolohichnykh statei Ivana Franka / Uporiad. D. Pavlychko. Kyiv : Vyd. dim «Kyievo-Mohylianska akademiia». Pp. 448-467. (in Ukrainian).

15. Shevchenko T. (2013). Kobzar [Kobzar] / Uporiad., vst. st. R. Lubkivskoho ; iliustr. M. Storozhenka. Lviv : Svit. 408 p. (in Ukrainian).

DOI: https://doi.org/10.17721/2520-2626/2020.27.18 УДК 261.7

\author{
Микола Обушний \\ доктор політичних наук, професор, \\ професор кафедри політології, \\ провідний науковий співробітник \\ Центру українознавства фрілософрського фракультету, \\ Київський національний університет імені Тараса Шевченка
}

ORCID: 0000-0002-9121-5095

E-mail: mobushnyy@gmail.com

\title{
«РУССКИЙ МИР» - НЕОІМПЕРСЬКА ІДЕОЛОГЕМА СУЧАСНOÏ POCIII
}

Анотація. Розкривається сутність неоімперської ідеологеми ${ }^{1}$ «русский мир», поява якої пов'язується з необхідністю ідеологічного обгрунтування експансіоністської політики сучасної Росії після розпаду комуно більшовицької імперії - Радянського Союзу. Тим більше, що підгрунтя для реанімації та створення нової імперії все ще зберігалося. До влади у новостворених державах, колишніх пострадянських республіках, у переважній більшості прийшли колишні партійні керівники, які зовсім, або ж мало прагнули ліквідації старої, за своєю суттю, авторитарно-тоталітарної системи політичного правління, майже усі вони прагнули зберегти і ті економічні зв'язки, що були встановлені у єдиному народногосподарському комплексі між республіками колишнього Радянського Союзу. Додаткові можливості для нової неоімперії надавав і створений у грудні 1991 року Союз незалежних держав (СНД). За таких умов прокремлівські теоретикивеликодержавники активно включилися у розробку ідейно-теоретичних засад нової ідеологеми. Проте саму назву «русский мир» було введено у науковий та політичний обіг лише у 2005 р. 3 цього часу просторові межі ідеологеми «русский мир» постійно розширюються і нині включають ті країни і народи «где слышна русская речь». ${ }^{2}$ Таким чином, головна мета нової ідеологеми «русский мир» домогтися включення у межі російської неоімперії не тільки саму Росію, але і усе російське зарубіжжя, тобто «..майже третину - міліард російськомовних людей або майже кожного двадиятого мешкания Землі» (О. Батанова). Тим самим, на думку великодержавників, можливо буде виправити геополітичну помилку, пов'язану з розпадом Радянського Союзу.

Доведено, що в основі неоімперської ідеологеми «русский мир» покладений російський ультранаціоналізм, який пронизаний ідеями панросіянізму, російської винятковості, сильної державності, які нині уособлює В. Путін. Ця особливість ідеологеми «русский мир» вказує на їі неоімперську спрямованість та геополітичні наміри великодержавницької політики сучасної Росії.

1 Поняття «ідеологема» дослідниками тлумачиться неоднаково. Одні вважають, що ідеологема - це мовленнєва одиниця, навантажена ідеологічними смислами (М. Бахтін), другі вживають термін «ідеологема» для позначення найменшого смислового елемента, в дискурсі конфліктів соціальних класів (Ф. Джеймсон), треті виходять з того, що поняття «ідеологема» емоційно забарвлене, тому має переважно символічний характер, що ріднить її з міфологемою і т.д. У «Філософському енциклопедичному словнику» (Київ, Абрис, 2002 р. С. 234) ідеологема визначається як «назва ключового конструкту» (елемента) будь-якої ідеологічної системи; цінність, пов'язана із іншими винятково значущими цінностями, те, що є предметом віри і довіри. У даній статті поняття «ідеологема» «русский мир» використовується як ключовий елемент ідеологічної системи, що нині є домінуючим у свідомості не тільки у правлячого класу сучасної Росії, але і у переважаючій більшості росіян (на жовтень 2020 р.)

${ }^{2}$ https://www.ng.ru/politics/1999-12-30/4_millenium.html.. 